\title{
Science Teachers' Level of Technological Knowledge and the Effect of Demographic Variables in Ondo State, Nigeria
}

\author{
Olajumoke Toye Ominowa ${ }^{1 *}$ (B)
}

${ }^{1}$ Adekunle Ajasin University Akungba-Akoko (AAUA), NIGERIA

*Corresponding Author: ominowaolajumoke@gmail.com

Citation: Ominowa, O. T. (2022). Science Teachers' Level of Technological Knowledge and the Effect of Demographic Variables in Ondo State, Nigeria. European Journal of Interactive Multimedia and Education, 3(1), e02202. https://doi.org/10.30935/ejimed/11437

\begin{abstract}
This study examines the level of Ondo State science teachers' Technological Knowledge (TK) and the effect of demographic variables such as school geographical location and gender, with a view to bring about effective teaching of science concept through integration of technology. This study is based on survey research design. The population comprised all science teachers in public secondary schools in Ondo State. Data was collected from 628 science teachers across the three senatorial districts in the State. The instrument used was technological knowledge questionnaire and a reliability coefficient $r=(0.93)$ was obtained using Cronbach Alpha. Two research hypotheses and one question were posed to guide the study. Findings from this study revealed that $66.9 \%$ of science teachers in Ondo State have low level of TK, a significant difference between the TK of rural and urban teachers and no significant difference between the TK usage between female and male teachers. It is recommended that government should develop a comprehensive framework for professional development that will assist teachers to develop skills to teach in the $21^{\text {st }}$ century environment.
\end{abstract}

Keywords: technological knowledge, science, teachers, rural, urban

Received: 19 Sep. $2021 \bullet$ Accepted: 9 Dec. 2021

\section{INTRODUCTION}

The vast knowledge in science is relevant and applicable in all areas of life endeavours, without which life on the planets would be miserable and primitive (Tavares et al., 2021). Many of the developed nations were able to achieve so much in science and technology because of the knowledge acquired through science education in institutions of learning, which is applied in the production of various human necessities.

In the light of the contribution of science to enhancing the quality of life, it is safe to conclude that to promote the prosperity of any nation, there is need for more trained scientists. However, it is worrisome that science had been tagged by learners as complicated, abstract, uninteresting and boring (Ugwuanyi \& Okeke, 2020a). This perception accounted for one of the reasons for poor performance of students in the Senior Secondary Certificate Examination (SSCE) over the years in Nigeria as shown in Table 1.

Table 1 shows the yearly decline in enrolment and students under achievement in science which clearly shown that science education is in danger since learners of science are no longer interested in science particularly in Nigeria. This has serious implication for her social and economic development.

The WAEC chief examiners report for 2018 linked the underachievement of the students to incorrect information they received from science teachers who are not acquainted with the latest knowledge in science, lacks skills in the integration of technology to the teaching and learning of science, absence of teachers in seminars and workshops and lack of teaching skill which embrace modern technologies.

Iheonunekwu (2019) opined that to enhance learning in science, teachers need to have a focus on the relationship that exists between the educational task, the scientific concepts and technological tool that students use in responding to the task. He further noted that, majority of teachers and schools are paying more attention to pedagogy and content, forgetting the technological domain. The current discussion on teaching and learning all around the world is demanding the adoption of the learner-centered approach which requires the use of educational technologies which allows students to engage in a flexible learning irrespective on school location.

Since, teaching of science globally has taken a dynamic approach in the $21^{\text {st }}$ century. The era of technology has come to stay and teaching is expected to be facilitated by the use of technology. This is supported by Yildirim and Sensoy (2018) that educational system is faced with increasing pressure to use new technologies to teach students the knowledge and skills they need in the $21^{\text {st }}$ century.

Despite the global needs for integration of technology in teaching of science subjects with the view to promote higher order thinking, meaningful learning and greater engagement of students that will bring 
Table 1. Trends of students' performance in biology, chemistry, and physics in the West African School Certificate Examination May/June 20162019 in Nigeria

\begin{tabular}{|c|c|c|c|c|c|c|c|c|c|}
\hline \multirow[t]{2}{*}{ Year } & \multicolumn{3}{|c|}{ Biology } & \multicolumn{3}{|c|}{ Chemistry } & \multicolumn{3}{|c|}{ Physics } \\
\hline & Total Entry & $\begin{array}{c}\text { Credit Pass } \\
\left(\mathrm{A}_{1}-\mathrm{C}_{6}\right)\end{array}$ & $\begin{array}{c}\% \\
\text { Pass }\end{array}$ & Total Entry & $\begin{array}{c}\text { Credit Pass } \\
\left(\mathrm{A}_{1}-\mathrm{C}_{6}\right)\end{array}$ & $\begin{array}{c}\% \\
\text { Pass }\end{array}$ & Total Entry & $\begin{array}{c}\text { Credit Pass } \\
\left(\mathrm{A}_{1}-\mathrm{C}_{6}\right)\end{array}$ & $\begin{array}{c}\% \\
\text { Pass }\end{array}$ \\
\hline 2016 & $1,200,367$ & 740,345 & 61.68 & 706,873 & 408,122 & 57.74 & 705,125 & 415,655 & 58.95 \\
\hline 2018 & 92,758 & 46,745 & 53.28 & 56,565 & 19,856 & 36.48 & 56,558 & 27,309 & 49.94 \\
\hline 2019 & 78,498 & 38,341 & 51.43 & 48,250 & 18,998 & 40.98 & 48,259 & 19,717 & 42.32 \\
\hline
\end{tabular}

Source: West African Examination Council, Nigeria (2020)

significant novelties to teachers and classroom instructions which would make the learners to be more interested in science. Researches have shown that in Nigeria many teachers earned degrees at a time when educational technology was at a very different stage of development than it is today. This have resulted to the reasons why teachers are not sufficiently prepared to use technology in the classroom and often do not appreciate its relevance to teaching in the classroom because they believed that acquiring a new knowledge base and skills could be time consuming activity due to their busy schedule.

Location of schools was reported by Kaur \& Arya (2019) and Sejah (2021) to be a potential reason for the rural-urban differences in teachers' integration of technology in their teaching process. These prevailing conditions imply that learning opportunities in Nigeria schools differ from school to schools.

Luik et al. (2018) and Ozudogru and Ozudogru (2019) observed gender disparity in the use of technology in the teaching and learning process. They affirmed that many feminists reject technology to a greater extend and so not familiarized with technological knowledge and its didactic application in teaching and this affect how educator prepare student-teachers to teach with technology. It is against this background that this study investigates science teachers' level of technological knowledge and effect of teachers' demographic variable such as teachers' gender and school location in teaching profession in senior secondary schools in Ondo State.

\section{Statement of the Problem}

The under achievement of science students in Senior Secondary Schools Certificate Examination (SSCE) has been linked to incorrect information they received from their teachers who are not acquainted with the latest knowledge in science and lacks skills in the integration of technology to the teaching and learning of science (WAEC, 2018). Hence, the focus of this study is to investigate the level of science teachers' technological knowledge in teaching profession in senior secondary schools in Ondo State.

\section{Objective of the Study}

The study investigated the level of science teachers' technological knowledge and the effect of demographic variables in the teaching profession. Specifically, the study aimed to:

1. find out the level of Technological Knowledge (TK) of science teachers in Ondo State,

2. investigate the difference between the Technological Knowledge (TK) of urban and rural science teachers in Ondo State, and

3. find out if there is any difference between the Technological Knowledge (TK) of male and female science teachers in senior secondary schools in Ondo State.
Our research question $(\mathbf{R Q})$ can be defined, as follows:

RQ: What is the level of the technological knowledge of science teachers in Ondo State?

Our hypotheses can be listed, as follows:

H1: There is no significant difference in the Technological Knowledge (TK) of science teachers in the urban and rural areas in Ondo State.

H2: There is no significant difference between male and female science teachers use of Technological Knowledge (TK) usage in teaching science in Ondo State secondary schools.

\section{RESEARCH METHOD}

Descriptive survey research method was utilized for the study. This enabled the researcher to capture large sample size. The population of this study comprised all science teachers in Ondo State. Multistage sampling procedure was used to select 628 science teachers from all the three senatorial districts in Ondo State. Technological Knowledge Questionnaire (TKQ) adapted from Sahin (2011) was used by the researcher to measure the level of science teachers' technological knowledge. The instrument was validated by experts in the Department of Science Education, Adekunle Ajasin University, Akungba-Akoko. A field trial of TKQ was attempted on 20 science teachers who were nonparticipants in this study. Cronbach Alpha was used to determine the internal consistency of the instrument. This yielded reliability coefficient of 0.93 . This shows that the instrument is reliable. The questionnaire was administered by the researchers and research assistants. The data collected were analysed using frequency counts, percentage and t-test at 0.05 alpha level.

\section{RESULTS}

\section{Research Question}

In answering the research question (What is the level of the technological knowledge of science teachers' in Ondo State?), the data obtained from TKQ questionnaire were subjected to frequency counts and percentages. The scores were distributed as low, moderate, and high scores. 1-2 scores were categorized as low; 3 was tagged as moderate; and 4-5 was termed as high. The results are presented in Table 2 and Figure 1. 
Table 2. Descriptive statistics of the level of science teachers' technological knowledge (TK) in Ondo State

\begin{tabular}{ccc}
\hline TK level & Frequency & Percentage (\%) \\
\hline Low & 420 & 66.9 \\
\hline Moderate & 161 & 25.6 \\
\hline High & 47 & 7.5 \\
\hline
\end{tabular}

Results from Table 2 show that $66.9 \%$ of the science teachers possessed a low level of technological knowledge, $25.6 \%$ of them possessed a moderate level of technological knowledge while $7.5 \%$ of the science teachers had high level of technological knowledge. These results indicated that majority of science teachers in the study possessed a low level of technological knowledge. The results are further depicted in Figure 1.

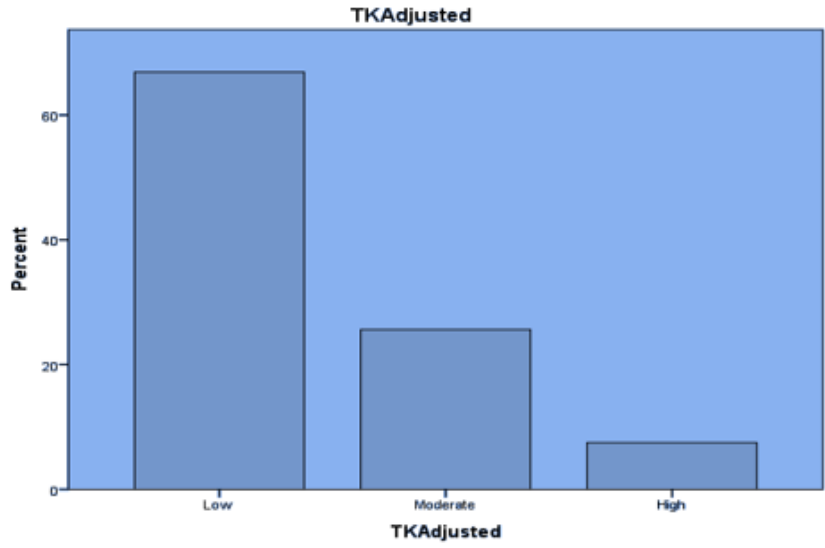

Figure 1. Level of Ondo State science teachers' TK

\section{Research Hypotheses}

\section{Hypothesis 1}

Our first hypothesis states that there is no significant difference in the Technological Knowledge (TK) of science teachers in the rural and urban areas in Ondo State.

Table 3 shows that there was a significant difference between the technological knowledge of rural science teachers' $(\overline{\mathrm{x}}=39.96, \mathrm{SD}=$ 14.31) and urban science teachers $(\overline{\mathrm{x}}=43.51, \mathrm{SD}=14.93)$; $\mathrm{t}(626)=3.01$, $\mathrm{p}<0.05$. These results indicated that teachers experience to technological knowledge differs based on school location. The null hypothesis is here by rejected.

Table 3. t-test analysis of technological knowledge (TK) of rural and urban science teachers

\begin{tabular}{|c|c|c|c|c|c|c|}
\hline $\begin{array}{c}\text { School } \\
\text { location } \\
\end{array}$ & $\mathrm{N}$ & $\overline{\mathbf{x}}$ & SD & df & $\mathbf{T}$ & Sig \\
\hline Rural & 270 & 39.96 & 14.31 & \multirow{2}{*}{626} & \multirow{2}{*}{3.01} & \multirow{2}{*}{$0.003^{*}$} \\
\hline Urban & 358 & 43.51 & 14.93 & & & \\
\hline
\end{tabular}

Table 4. t-test analysis of technological knowledge (TK) usage in teaching based on gender of science teachers

\begin{tabular}{|c|c|c|c|c|c|c|}
\hline Gender & $\mathbf{N}$ & $\overline{\mathbf{x}}$ & SD & df & $\mathbf{T}$ & Sig \\
\hline Female & 392 & 41.65 & 14.74 & \multirow{2}{*}{626} & \multirow{2}{*}{0.738} & \multirow{2}{*}{0.461} \\
\hline Male & 236 & 42.55 & 14.83 & & & \\
\hline
\end{tabular}

\section{Hypothesis 2}

Our second hypothesis states that there is no significant difference between male and female science teachers' use of Technological Knowledge (TK) in teaching science in Ondo State Secondary Schools.

Results from Table 4 show that there was no significant difference between the technological knowledge usage in teaching between female science teachers $(\overline{\mathrm{x}}=41.65, \mathrm{SD}=14.74)$ and male science teachers' $(\overline{\mathrm{x}}=$ $42.55, \mathrm{SD}=14.83) ; \mathrm{t}(626)=0.738, \mathrm{p}>0.05$. This implies that gender has no influence on science teachers' use of technological knowledge in Ondo State secondary schools. The null hypothesis is hereby not rejected.

\section{DISCUSSION}

The results of this study showed that majority of science teaches in this study possessed a low level of technological knowledge and therefore are still operating at level 1 of Jen et al. (2016) scale which connotes lack of technology use. This finding is in tandem with the findings of Farrell and Hamed (2017). The findings contradict the findings of Holland and Piper (2015)

The results of this study also showed that there was a significant difference in the technological knowledge of science teachers in the urban and rural areas. The results of this study agreed with the findings of Jeyaraj and Ramnath (2018) and Sejah (2021). This result did not support the findings of Wang (2013) and Wang et al. (2019).

The results of this study further showed that there was no significant difference in the Technological Knowledge (TK) usage in teaching between male and female science teachers. The finding of this study is in variance with the work of Luik et al. (2018) and Ozudogru \& Ozudogru (2019). This result did not support the findings of Jang and Tsai (2012), Spazak (2013), Karaca (2015), and Roig et al. (2015).

\section{CONCLUSIONS AND RECOMMENDATIONS}

The male and female science teachers do not differ significantly in technological knowledge. However, there existed a significant difference in the technological knowledge of rural and urban science teachers.

Based on the findings, it is recommended that necessary attention should be accorded to science teachers' computer literacy and operation in the secondary school. In addition, government should equip both the urban and rural public schools with necessary ICT facilities which will enhance integration of technology in science classroom.

Funding: The author received no financial support for the research and/or authorship of this article.

Declaration of interest: The author declares no competing interest.

Data availability: Data generated or analysed during this study are available from the author on request. 


\section{REFERENCES}

Farrell, I. K., \& Hamed, K. M. (2017). Examining the relationship between Technological Pedagogical Content Knowledge (TPACK) and student achievement utilizing the Florida value-added model. Journal of Research on Technology in Education, 49(3-4), 161-181. https://doi.org/10.1080/15391523.2017.1328992

Holland, D. D., \& Piper, R. T. (2015). Testing a technology integration education model for millennial preservice teachers: Exploring the moderating relationships of goals, feedback, task value and selfregulation among motivation and technological, pedagogical, and content knowledge competencies. Journal of Educational Computing Research, 54(2), 196-224. https://doi.org/10.1177/ 0735633115615129

Iheonunekwu, S. (2019). Pedagogy of technology integration in teaching and learning. GRIN Verlag.

Jang, S.-J., \& Tsai, M.-F. (2012). Exploring the TPACK of Taiwanese elementary mathematics and science teachers with respect to use of interactive whiteboards. Computers \& Education, 59(2), 327-338. https://doi.org/10.1016/j.compedu.2012.02.003

Jen, T.-H., Yeh, Y.-F., Hsu, Y.-S., Wu, H.-K., \& Chen, K.-M. (2016). Science teachers' TPACK-Practical: Standard-setting using an evidence-based approach. Computers \& Education, 95, 45-62. https://doi.org/10.1016/j.compedu.2015.12.009

Jeyaraj, I., \& Ramnath, R. (2018). A study on technological pedagogical and content knowledge of B. ed student teachers in Puducherry region. World Wide Journal of Multidisciplinary Research and Development, 4(1), 306-308.

Kaur, P., \& Arya, S. (2019). Attitude towards information and communication technology among rural and urban primary and secondary school teachers of Punjab. International Journal of Trend in Scientific Research and Development, 3(3), 859-864. https://doi.org/10.31142/ijtsrd23131

Luik, P., Taimalu, M., \& Suviste, R. (2018). Perceptions of technological, pedagogical and content knowledge (TPACK) among pre-service teachers in Estonia. Education and Information Technologies, 23, 741-755. https://doi.org/10.1007/s10639-0179633-y
Ozudogru, M., \& Ozudogru, F. (2019). Technological pedagogical content knowledge of mathematics teachers and the effect of demographic variables. Contemporary Educational Technology, 10(1), 1-24. https://doi.org/10.30935/cet.512515

Roig, R., Mengual, S., \& Quinto, P. (2015). Primary teachers' technological, pedagogical and content knowledge. Comunicar, 4(5), 151-159. https://doi.org/10.3916/C45-2015-16

Sahin, I. (2011). Development of survey of technological pedagogical and content knowledge (TPACK). TOJET: The Turkish Online Journal of Educational Technology, 10(1), 97-105.

Sejah, P. (2021). Teacher's attitude towards information technology in relation to their gender, locality and type of school. International Research Journal on Advanced Science Hub, 3(3), 92-95. https://doi.org/10.47392/irjash.2021.072

Spazak, L. (2013). Secondary pre-service teachers' perception of preparedness to integrate technology $[\mathrm{PhD}$ dissertation, Indiana University of Pennsylvania]. ProQuest Dissertations Publishing.

Tavares, R., Vieira, R. M., \& Pedro, L. (2021). Mobile app for science education: Designing the learning approach. Journal of Education Science, 11, 79. https://doi.org/10.3390/educsci11020079

Ugwuanyi, C. S., \& Okeke, C. I. O. (2020a). A multimedia instructional package on for enhancing achievement in basic science. International Journal of Advanced Science and Technology, 136(1), 5160. https://doi.org/10.33832/ijast.2020.136.05

WAEC. (2018). Senior secondary certificate examinations chief examiners' report. https://www.waeconline.org.ng

Wang, J., Tigelaar, D. E. H., \& Admiraal, W. (2019). Connecting rural schools to quality education: Rural teachers' use of digital educational resources. Computers in Human Behavior, 101, 68-76. https://doi.org/10.1016/j.chb.2019.07.009

Wang, P. (2013). Examining the digital divide between rural and urban schools: Technology availability, teachers' integration level and students' perception. Journal of Curriculum and Technology, 2(2), 127 139. https://doi.org/10.5430/jct.v2n2p127

Yildirim, H. I., \& Sensoy, O. (2018). Effect of science teaching enriched with technological practices on attitudes of secondary school 7th grade students towards science courses. Universal Journal of Educational Research, 6(5), 947-959. https://doi.org/10.13189/ ujer.2018.060516 